\title{
The Danube strategy in the context of development of rural areas in Eastern Croatia: the role of civil society organizations
}

\author{
Damir DemonjaA ${ }^{*}$, Tihana Stepinac Fabijanić ${ }^{\mathrm{B}}$ \\ Received: March 1, 2016 | Revised: April 12, 2017 | Accepted: May 27, 2017 \\ DOI: $10.18421 / G P 21.02-06$
}

\begin{abstract}
The analyses made on the Danube Strategy shows that it is highly applicable in the economic segment of development of rural areas in Eastern Croatia (Croatian Danube Region). Potentials of development of rural areas in Eastern Croatia, as part of the Danube Basin, can be applied with a higher quality through a common action of all interested stakeholders. Results achieved so far by the civil society associations/organizations in Eastern Croatia through projects/activities/experiences in development of rural areas acknowledge that local and regional initiatives are important facilitators of sustainable development in the Danube Region. This justifies the future role and activities of the Danube Civil Society Forum (DCSF) in promoting and extending the participation of civil society and its networking in the frame of the Danube Strategy and in development of rural areas in Eastern Croatia. The paper discusses the role and importance of the Danube Strategy and its implications in relation to Croatia. Then interpret the initiative of connecting the Danube Region at the level of civil society associations/organizations networks, with particular emphasis on the role of the Danube Civil Society Forum (DCSF) as a network of civil society associations/organizations of the Danube Basin. The paper, also, lists examples of successful European and Croatian civil society associations/organizations, and, finally, lists activities and experiences in the field of development of rural areas in Eastern Croatia (Croatian Danube Region).
\end{abstract}

Keywords: Eastern Croatia, Danube Strategy, civil society associations/organizations, Danube Civil Society Forum (DCSF), development of rural areas

\section{Introduction}

European Union Strategy for the Danube Region (EUSDR), or Danube Strategy, represents one of the most important initiatives of the European Union related to the strong integration of large areas of Europe by Danube River and creation of an appropriate framework for better and more open social, econom- ic, environmental and cultural development. The purpose of the Strategy is to strengthen territorial cooperation and interaction between the Danube Region, ensuring sustainable development of each region with better transport and social cohesion, environmental protection, raising the level of education, culture, tourism, energy, labor market, and other, also build-

A Institute for Development and International Relations, IRMO, Department of International Economic and Political Relations, Ljudevita Farkaša Vukotinovića 2, 10000 Zagreb, Croatia; ddemonja@irmo.hr

B Croatian Academy of Sciences and Arts, Institute for Historical and Social Sciences in Rijeka, Ružićeva 5, 51000 Rijeka, Croatia; tihana.fabijanic@post.t-com.hr

* Corresponding author: Damir Demonja, e-mail: ddemonja@irmo.hr 
ing prosperity and strengthening the institutional cooperation within the Region. In this sense of great importance are local and regional initiatives as drivers of sustainable development of the Danube Region. As a good example stands out the Danube Civil Society Forum (DCSF) as a network of civil society associations/ organizations of the Danube Basin, which functions as a kind of platform to promote and intensify the activities of civil society, and their effective networking within the framework of the Danube Strategy.

The theme of this paper is regional development of the Croatian Danube Region in the framework of the Danube Strategy, in particular the possibilities for development of rural areas in Eastern Croatia through the activities of the civil society associations/organizations. The purpose of this paper is to highlight the importance of the Danube Strategy, point the potential role of DCSF in regional and cross-border cooperation, list the examples of successful civil society associations/organizations from Europe and Croatia, and allocate activities and experiences in the development of rural areas in Eastern Croatia.

\section{Literature review/Previous Research}

The theme of the Danube Strategy is a new area that is beginning to research since its implementation that began in June 2011 (Demonja, Stepinac Fabijanić, 2012; Čvrljak, 2011). Danube Strategy was discussed at various meetings, seminars and conferences, and thoughts/ views from such events are mostly unpublished. On the other hand, there are plenty of online documents and only a small number of relevant papers/texts, especially analysis, findings and recommendations on the Danube Strategy published in Europe. For instance, with the macro-regional research along the Danube deals The Blue Ribbon Research Centre (BRRC), established in 2009 in Budapest, Hungary, which one of the topics is the Danube Strategy as well. It is an academic network established for the research of the Danube Strategy as a new European project (Agh, et al., 2010; Schymik, 2011). The recent significant research contribution on the Danube Strategy in Croatia provides the Proceedings of the scientific conference "Danube Strategy Strategic Significance for Serbia" (Jeftić Šarčević, Stojić Karanović, 2012), held in 2011 in Belgrade, in which are published scientific contributions by Croatian authors. Of the importance for the theme of this paper is the article that wrote D. Demonja and T. Stepinac Fabijanić (Demonja, Stepinac Fabijanić, 2012) which interprets the Danube Strategy and its importance for Croatia, presents and analyzes the structure, objectives, tasks and DCSF operation mode, as well as the role of Croatia in the respective network, especially in the fields of culture and tourism, and, finally, presents certain Cro- atian projects which are important for the promotion of Croatian culture and tourism as priority projects of the Croatian Danube Region within the framework of the Danube Strategy. In the above mentioned context, this paper presents a rare contribution to the scientific research of this topic in Croatia.

\section{Methodology}

Work methodology of presented topic was consisted of collecting existing relevant literature and documents related to the Danube Strategy, information and results of the actions of civil society associations/ organizations related to activities, projects and work in the field of development of rural areas in Eastern Croatia, as well as other data from secondary sources, and from the Internet, and the analysis and interpretation of collected data.

\section{Discussion}

\section{The genesis of the Danube Strategy development} European Union Strategy for the Danube Region (EUSDR), or Danube Strategy, is one of the most important European Union initiatives which form the basis for the structure/organization of modern regional group of countries in the international river basin of the river Danube. It provides strong support for the development of all Danube countries whether are members of the European Union or not, guided by the principles of responsible use of natural resources for sustainable development. Taking into account the overall importance of the Danube River as an international corridor routes, and water potential of the 21st century, which will surely become the most important and most sought natural resource (much higher than currently overvalued oil and gas), yet neither Croatia nor the countries in the region (surrounding) have no systematic approach, as well as not enough awareness of the importance and necessity of a comprehensive strategy for sustainable use of the Danube River. There are some scientific studies and articles, few strategies, but still insufficient public consciousness and legislation that would facilitate and direct the sustainable use of the Danube River and all its potential. Croatia has already noticed the opportunities arising from the fact that the Danube River flows through it, in a length of $188 \mathrm{~km}$, it is the fourth-longest river in Croatia (after Sava, Drava and Kupa), and that Croatia participates with $4.5 \%$ of its Danube Region territory in the Danube macro-region. In this context, the Danube Strategy is of a strategic importance for Croatia.

In the process of designing the Danube Strategy, with the European Union institutions, the regions 
and local communities of the countries on the Danube were also included, as well as international organizations, financial institutions, socio-economic partners, academic community and civil society. The larger number of participants was provided by the horizontal line from different countries and organizations, while the vertical line did participants at the international, national, regional and local level. The Strategy was discussed by interested countries focused on the main issues in the four directions of cooperation: 1. connecting macro-regions, 2. protection of the environment, 3 . building prosperity, and 4. strengthening the macro-region. The Strategy defines cross-border, inter-regional and international cooperation as a priority within the European Union, and in the context of enlargement, with the aim of removing the economic disparities.

The Danube Strategy was officially adopted at the European Council meeting on June 24, 2011 (Internet 13). This was confirmed by the Council of Ministers of the European Union, which at the meeting on April 13, 2011 accepted the proposal of the Danube Strategy that European Commission adopted in December 2010 (Council conclusions on the European Union Strategy for the Danube Region, 2011). The Strategy covers 14 European countries in the Danube River flow and a territory inhabited by 115 million people, and except European Union member countries the Strategy integrated countries covered by the Union's enlargement policy and neighborhood policy. In addition to Germany, Austria, Slovakia, Hungary, the Czech Republic, Slovenia, Romania and Bulgaria, the Danube Strategy also included Croatia (at that time not yet an EU member), Serbia, Bosnia and Herzegovina, Montenegro, Moldova and parts of Ukraine (European Union Strategy for the Danube Region, Action Plan).

The Danube Strategy covers different policies of the European Union (regional, transport, energy, environmental, security, and others) through the so-called integrated approach. Based on the principle of "three no"- no to new funding, no to new legislation, and no to creation of new institutions within the European Union, the focus is on firmer synergies between authorities at all levels to increase the positive clash of action and funding. This means that the Strategy must be developed and implemented without increasing the financial expenses and without new funding sources, entirely through the existing structures and institutions, and without the adoption of the new legal framework and instruments.

Thus, the Danube Strategy provides specific, concrete and comprehensive cooperation framework contained in its proposal and the accompanying Action Plan. The aim is to effectively face the challenges of the region (insufficient use of river waterways, ener- gy security, environmental protection, etc.), and the Strategy is based on four pillars: 1 . connecting the Danube Region, 2. protecting the environment in the Danube Region, 3. building prosperity in the Danube Region, and 4. strengthening the Danube Region (European Union Strategy for the Danube Region). These four pillars are the key goals, which are translated into action through the eleven priority areas, and 253 activities and measures, which have guidelines and deadlines (EU Strategy for the Danube Region, Priority Areas). As planned, by 2020 the Danube Region should become a region with an improved quality of life of citizens who live in it, with much more economic opportunities, with a number of innovative young companies that create (and open) new jobs, with a better environment, and a prosperous cultural climate.

\section{The Danube Strategy and Croatia}

Croatia, as the Danube Basin country, fully supports the idea of creating a joint European international space as proposed by the Danube Strategy. The Croatian Government has participated in the preparations for drafting the Danube Strategy and has adopted its final text (Internet 14). According to the process of Europeanization and the possibilities of cross-border cooperation, Croatian counties are included in the regional alliances or networks as, for example, in the macro-region of the Danube Basin, which guarantees equal representation of all regions on the Danube. By signing the Stabilization and Association Agreement and with the takeover of the obligations on the final alignment with the acquis, special attention is given to cross-border, transnational and interregional cooperation to facilitate economic development and reduce regional disparities.

In Vukovar, on April 29, 2011, Vukovar Danube Conference was held, hosted by the Croatian Government (Internet 22). The Conference stated support to the European Commission and to all participating countries of the Strategy to joint initiative and the implementation of projects defined in the Action Plan of the Strategy for development of the Danube flow. Croatian participation in this strategic European project opens up new opportunities for socio-economic development of the Pannonian Croatia through the implementation of cross-border and transnational projects in the Danube Region, as well as to strengthen institutional capacity and the application of experience and knowledge acquired in the Croatian accession negotiations.

In development of Croatian contribution to the Danube Strategy, principle of harmonization of national priorities in sectoral strategies with regional operational programs of development was applied. Positions of Croatian counties according to their development strategies are previously agreed. Among 
the main development priorities of Croatian counties on the Danube are entrepreneurship development, modernization of agriculture, and tourism development. Croatia, in the context of the region, according to homogeneous characteristics (natural and sociogeographic), is separated/isolated in south-eastern Europe, and already has perennial good cooperation in the frame of certain priority areas of the Strategy.

\section{Initiatives of the connecting the Danube Region at the level of civil society associations/ organizations networks}

In the frame of the Danube Strategy, civil society plays a major role in the realization of its concept and contextual framework. Special attention is directed to civil society associations/organizations as stakeholders in the implementation of the operational action plans and objectives of the Strategy. As research shows, almost all public stakeholders (member states, those that are not, European Commission) invite for the inclusion of civil society in the implementation of the Strategy, although they do not have a clear idea of how to achieve it (Lutgenau, 2010).

Civil society associations/organizations, regardless of whether they are regional, national or international, are trying to incorporate the Strategy but remain on informal levels of participation, mainly dependent on their own networking opportunities and funding, attending decision-making processes of stakeholders, for example by participating in the conferences. At the international level stands out the Danube Civil Society Forum (DCSF) as a platform for civil society dialogue and networking in the Danube Region in the framework of the Danube Strategy.

\section{Danube Civil Society Forum (DCSF) - \\ functioning, intentions, goals, results}

Danube Civil Society Forum (DCSF) was founded on the First General Assembly held on June 30 and July 1, 2011, in Eisenstadt (Železno) in Austria, has 112 members of which 74 are regular members and 38 are observers/monitors (Internet 3). DCSF is directed to support civil society organizations in the Danube Region in order to promote and improve participation and networking of civil society in the framework of the European Union Strategy for the Danube Region (EUSDR) (Internet 2). The most important objectives of the DCSF are (Internet 24):

- to support and promote the Danube Strategy following the principles of respect for democracy and human rights, the rule of law, good governance, principles of market economy, and social and environmental sustainable development,

- to support the existing non-governmental organizations, the creation of independent and au- tonomous non-governmental organizations, to strengthen the capacity of civil society, and to support, assist and coordinate the efforts of its members,

- to promote a culture of dialogue and cooperation between civil society organizations and between civil society and public and private actors in the Danube Basin, and

- to promote dialogue and solidarity between peoples and cultures.

DCSF is focused on networking and projects related to the actions in its Working Groups. Until now, four Working Groups have been formed, related to the four pillars of the Danube Strategy (European Union Strategy for the Danube Region, Priority Areas). These is done so that creativity and activity incorporated in this Working Group sare compatible with the overall Danube Strategy. The four pillars of the Strategy (Internet 4) and the four Working Groups (WG) (Internet 5) are: WG 1: Connecting the Danube Region, WG 2: Protecting the environment in the Danube Region, WG 3: Building prosperity in the Danube Region, and WG 4: Strengthening the Danube Region. All four listed thematic areas are based on the interdisciplinary/multidisciplinary comprehensive approach. In order to enable civil society networking on specific issues of trans-regional importance, in each Working Group a Sub-Group was formed to deal with specific thematic or regional areas.

In the frame of the Danube Strategy, DCSF actively participate in the implementation and monitoring of the Danube Strategy, the building of inter-regional dialogue and understanding, and the building a civil society and active citizens in the region.

Some of the expected key results of DCSF organization/structure are:

- enhanced inter-regional and international cooperation and networking of civil society in the Danube Region,

- the increased influence of civil society in democratic decision-making processes on issues relating to the Danube Region,

- the increased ability of civil society in shaping opinion and the promotion of the Danube Strategy and its objectives in the region, and

- strengthened cooperation between civil society and public and private authorities in the Danube Region and in the European Union.

Representatives of the working bodies of the DCSF operate solely on voluntary principles: working groups and their members communicate electronically, and direct meetings and working in groups for the purpose of mutual exchange of information are provid- 
ed, conducting activities through projects, etc. Finally, it should be pointed that the DCSF has primarily a consulting role among civil society associations/organizations of the Danube Region, and supports and promotes their activities related to the Action Plan of the Strategy, as well as in relation towards civil society associations/organizations to public and private institutions on regional and national level, and within the European Union and its bodies.

\section{Examples of other successful European and Croatian civil society associations/organizations}

In a similar way like the DCSF, with a differently developed work programs functioning some other European networks of civil society associations/organizations, organized solely for the purpose of direct involvement in the activities of the Danube Strategy.

Since 2010, in Hungary, in Budapest, act organization DaNet - Danube Net (Internet 9), which in 2011 began with a series of conferences on the subject of the Danube Strategy and its implementation as part of the activities of the civil society of the Danube Basin, including in the membership participating civil society associations/organizations. In Ukraine, Odessa, is founded the Center for Regional Studies, which brings together researchers, public stakeholders and experts in the field of regional development and, among other, deals with sustainable development and protection of the area of the Danube Delta on the basis of the design and implementation of research and professional projects of sustainable development of the region (Internet 1). Danube Cultural Cluster - Collegium Hungaricum, in Vienna, Austria, is the umbrella organization for cultural networking of present and future cultural clusters in the Danube Region, and its activities are, among other, presented at numerous conferences (Internet 6). International Danube Tourist Commission, in Vienna, Austria, connects Germany, Austria, Slovakia, Hungary, Croatia, Romania and Serbia through their principal tourist boards' offices, which thus participate in joint marketing activities related to tourism and its products of the Danube Basin areas of the listed countries (Internet 18). Finally, the Danube Delta Eco-Tourism Museum Center from Tulcea, Romania, has the role of promoting the development of ecotourism in Romania's Danube Delta as the only way of sustainable development in protected areas, and raising awareness of local stakeholders and tourists on the regional identity of the Romanian Danube Delta (Internet 7).

Regarding the Croatian examples of civil society associations/organizations, only few of them are directly involved in activities related to the Strategy and joined the DCSF network, and among them is the Croatian Section of ECOVAST (European Council for the
Village and Small Town) (Internet 10), together with the Croatian Rural Development Network (HMRR) (Internet 15). Within HMRR, with its activities on the trail of the Danube Strategy, few associations stand out, but at the time of writing this paper, these associations have not been directly involved in the activities of the Danube Strategy. Before all, stands out the civil society association Slap from Osijek (Internet 23), with whom the DCSF before founding Assembly came into contact, and in April 2011 organized a workshop in Osijek with the aim of informing interested civil society associations/organizations of the Osijek-Baranja Region about relevant documents of the Danube Strategy and DCSF program (Internet 11). The foundation of Local Action Groups, LAGs, in accordance with the IPARD European Union Programme and the objectives of the LEADER approach, in Eastern Croatia, of which stand out LAG Baranja (Internet 16), and LAG Vuka-Danube that covers areas of Antunovac, Erdut, Ernestinovo, Šodolovci, Vladislavci and Vuka (Internet 17) creates a solid basis for effective cooperation at the level of civil society in the framework of the Danube Strategy.

\section{Projects and activities for development of rural areas in the Croatian Danube Region}

In the Croatian Danube Region various projects of encouraging development of rural areas through tourism are already in the implementation, and they are developing as transnational. They are in various stages of development or implementation, with specific and distinctive effects that contribute to the sustainable development of the region. At the same time, these projects confirm the so-called "Danube identity" of Croatia. They are mainly carried out by the governing bodies of the Vukovar-Srijem and Osijek-Baranja County, as well as by their regional development agencies, and some ministries participate in these projects, such as those of culture and tourism. Among the projects related to derive development of rural areas in Eastern Croatia through tourism stand out „Datourway" (Klarić, 2011), "Danube bicycle route EuroVelo 6" (Internet 12), and others, while of development projects of rural areas in Eastern Croatia connecting culture and tourism stand out "Danube - path of culture" (Internet 21) and "Danube Limes in Croatia" (Internet 8).

Vukovar-Srijem County is very active in projects at the regional level (Internet 20). Since 2004, the County became a full member of the Working Community of Danube Regions established in 1990 in Wachau, Austria. The acting goal of Working Community of Danube Regions is the cross-border cooperation of the regions in the Danube area to stimulate economic development, transport, spatial planning, tourism, 
culture, science, and environmental protection. Promotion of cooperation between its members wants to contribute to the development of the Danube Region in the interests of the local population and peaceful cooperation in Europe. To this date, the Working Community of Danube Regions membership was approached 38 regions covering 650,000 square kilometers with about 80 million inhabitants of Europe. The most important Working Community of Danube Regions project for Croatia, concerning development of rural areas in Eastern Croatia through tourism, initiated by the Working Group "Economy and Tourism", is the concept of cycling routes along the Danube River (Internet 25).

Osijek-Baranja County, in the frame of the Danube Strategy, with respect to the area of tourism, predicted the apparent development of rural areas through the development of special forms of tourism, as well as the new tourism products, such as bicycle routes, wine routes, the restoration of castles, honey trails, old crafts and trades, revitalization of the Tvrđa (Fortress) in Osijek, etc. (Internet 19).

These projects and activities show that Croatia in the framework of the Danube Strategy can exploit the full potential of its regional characteristics for development of rural areas in Eastern Croatia and thus to develop them more effectively. In addition, the objectives of the rural improvement and development through tourism related projects and product in the Danube Strategy are complementary to those of Croatia. The Danube Strategy in those areas offers many opportunities to make better use of transnational and cross-border cooperation programs, which can relieve the entrepreneurial potential and with which the funds from the European Union can be obtained.

\section{Conclusion}

The Danube Strategy has been launched with the goal of comprehensive cooperation in Southeast Europe, and its activity is based on four main pillars of action, along with eleven priority areas with 253 activities and measures. These four main pillars are: 1. connecting the Danube Region, 2. protecting the environment in the Danube Region, 3. building prosperity in the Danube Region, and 4. strengthening the Danube Region.

Analysis of the Danube Strategy has shown that it is applicable in the field of development of rural areas in Eastern Croatia (Croatian Danube region), especially through rural tourism, as indicated mentioned examples. The potentials of truly development of rural areas in Eastern Croatia, as an integral part of the Danube Basin, with joint activities of all stakeholders can be well utilized in the improved tourist offer that Strategy promoted. So far achieved results of civ- il society associations/organizations in Eastern Croatia through projects/activities/experiences of development of rural areas using tourism and especially rural tourism, confirm that the local and regional initiatives are important drivers of sustainable development of the Danube Region. This is justified the future role and activities of DCSF as the most important and strongest network of civil society associations/organizations of the Danube Basin, with the intention of acting as a platform to promote and increase the participation of civil society and its networking in the Danube Strategy, and the further development of rural areas in Eastern Croatia.

Previous inadequate treatment of the Danube Strategy and the potentials of civil society in the framework of the Strategy in European and Croatian scientific literature limited the possibilities of its proper evaluation and possible implementation of concrete results in the treatment of the subject matter. However, the results of the few existing research that were related to the inclusion of the Strategy in the development processes of the Danube Region, as well as realized projects/activities, can be used to correct and supplement recent results of the development of rural areas in Eastern Croatia, to develop future development visions (plans, strategies), and directing further activities of civil society in terms of their active role in achieving sustainable development of Eastern Croatia.

\section{References}

Agh, A., Kaiser, T., Koller, B. (eds.). 2010. Europeization of the Danube Region: The Blue Ribbon Project. Blue Ribbon Research Centre King Sigismund College, Budapest.

Council conclusions on the European Union Strategy for the Danube Region. 3083rd General Affairs Council meeting, 13 April 2011, Brussels. Available online: http://www.consilium.europa.eu/uedocs/cms_data/docs/pressdata/EN/genaff/121511. pdf (20.01.2017)

Čvrljak, S. 2011. Danube Strategy as the EU's governance innovation concept. Medunarodne studije, 11, 4, 97-121. (in Croatian).

Demonja, D., Stepinac Fabijanić, T. 2012. Danube Civil Society Forum (DCSF) - an example of initiative to connect the Danube Region and opportunities of Croatia to promote culture and tourism in the framework of Danube Strategy. In Jeftić Šarčević, N., Stojić Karanović, E. [eds.]. Danube Strategy Strategic Significance for Serbia. Institute of International Politics and Economics, Belgrade, pp. 233252.

European Union Strategy for the Danube Region. Action Plan. Accompanying document to the com- 
munication From the Commission to the European Parliament, the Council, the European Economic and Social Committee and the Committee of the Regions. European Commission. Commission Staff Working Document. Available online: http:// www.danubestrategy.eu/fileadmin/danube/media/ EUSDR_action_plan_danube.pdf (20.01.2017)

European Union Strategy for the Danube Region, Priority Areas. Regional Policy - Inforegio. European Commission. Available online: http://ec.europa.eu/ regional_policy/sources/docoffic/official/communic/danube/action_plan_danube.pdf (20.01.2017)

European Union Strategy for the Danube Region. Communication From the Commission to the European Parliament, The Council, The European Economic and Social Committee and The Committee of the Regions. EUR-Lex Home. Id celex. Europa. Available online: http://eur-lex.europa.eu/LexUriServ/ LexUriServ.do?uri=CELEX:52010DCo715:EN:NOT (20.01.2017)

Jeftić Šarčević, N., Stojić Karanović, E. (eds.) 2012. Danube Strategy - Strategic Significance for Serbia. Institute of International Politics and Economics, Belgrade.

Klarić, Z. 2011. DATOURWAY: transnational strategy for the sustainable territorial development of the Danube area with a focus on tourism: national study Croatia. Institute for Tourism, Zagreb, $101 \mathrm{pp}$.

Lutgenau, S. A. 2010. Civil society participation in the European Danube Strategy. In Agh, A., Kaiser, T., Koller, B. [eds.]. Europeanization of the Danube Region: The Blue Ribbon Project. Blue Ribbon Research Centre King Sigismund College, Budapest, pp. 188-205.

Schymik, C. 2011. Blueprint for a Macro-Region. EU Strategies for the Baltic Sea and Danube Regions. German Institute for International and Security Affairs, Berlin.

\section{Other sources}

Internet 1: http://www.crs.org.ua/en/about.html (20.01.2017). Center for Regional Studies.

Internet 2: http://www.danubestrategy.eu/ (20.01.2017). Danube Civil Society Forum.

Internet 3: http://dcsf.danubestrategy.eu/danube-civil-society-forum-eu-strategy-danube-region/firstgeneral-assembly-danube-civil-society (20.01.2017). Danube Civil Society Forum. First General Assembly of the Danube Civil Society Forum.

Internet 4: http://dcsf.danubestrategy.eu/europeanunion-strategy-danube-region (20.01.2017). Danube Civil Society Forum. 4-pillar strategy.

Internet 5: http://dcsf.danubestrategy.eu/workinggroups (20.01.2017). Danube Civil Society Forum. Working Groups.
Internet 6: http://www.danubeculturalcluster.eu/ (20.01.2017). Danube Cultural Cluster.

Internet 7: http://icemtl.ro/danube-delta-eco-tourism-museum-center/ (20.01.2017). Danube Delta Eco-Tourism Museum Center.

Internet 8: http://limescroatia.eu/dunavski-limes-uhrvatskoj/ (20.01.2017). Danube Limes in Croatia.

Internet 9: http://groupspaces.com/DanubenetforNGO/ (20.01.2017). Danube Region Strategy. DaNet.

Internet 10. http://www.ecovast.hr/ (20.01.2017). ECOVAST Croatian Section.

Internet 11: http://www.ecovast.hr/index. php?option $=$ com_content $\&$ view $=$ article $\& i d=64$ : sastanak-foruma-dcsf-u-osijeku\&catid=10:novostiecovast-hr\&Itemid $=72(20.01 \cdot 2017)$. ECOVAST Croatian Section. Meeting of the DCSF Forum in Osijek.

Internet 12: http://www.eurovelo6-france.com/ (20.01.2017). EuroVelo 6.

Internet 13: http://europa.eu/rapid/pressReleasesAction.do?reference $=\mathrm{IP} / 11 / 124 \&$ format $=$ HTML\&age $\mathrm{d}=$ o\&language $=\mathrm{EN}$ \&guiLanguage $=$ en $(20.01 .2017)$. European Commissioner Hahn announces priority area coordinators for EU Strategy for Danube Region. Europa. Press Room. Press Releases.

Internet 14: https://vlada.gov.hr/sjednice/96-sjednica-vlade-republike-hrvatske/1106 (20.01.2017). 96th session of the Government of the Republic of Croatia.

Internet 15: http://www.hmrr.hr/ (20.01.2017). HMRR - Croatian Rural Development Network.

Internet 16: http://www.hmrr.hr/hr/leader/lagovi/lagbaranja/ (20.01.2017). HMRR - Croatian Rural Development Network. LAG Baranja.

Internet 17: http://www.hmrr.hr/hr/leader/lagovi/lagvuka-dunav/ (20.01.2017). HMRR - Croatian Rural Development Network. LAG Vuka-Dunav.

Internet 18: http://danubelimesbrand.org/project/ partners/international-danube-tourist-commission/ (20.01.2017). International Danube Tourist Commission.

Internet 19: http://www.slavonija.hr/images/Dokumenti2010/hr/Osje\%C4\%8Dko\%2o-\%2obaranjska\%20\%C5\%BEupanija\%2ou\%2okontekstu\%2oDunavske\%20strategije.ppt (20.01.2017). Presentation "Osijek-Baranja County in the context of the Danube Strategy".

Internet 2o: http://www.slavonija.hr/images/Dokumenti2010/hr/Vukovarsko\%2O-\%2osrijemska\%20 \%C5\%BEupanija\%2ou\%20\%2okontektsu\%2oDunavske\%20strategije.ppt (20.01.2017). Presentation „Vukovar-Srijem County in the context of the Danube Strategy".

Internet 21: http://www.min-kulture.hr/default. aspx?id=1717 (20.01.2017). Republic of Croatia. 
Ministry of Culture. Cultural Heritage. Danube path of culture.

Internet 22: http://www.mvpei.hr/MVP.

asp?pcpid=2600 (20.01.2017). Republic of Croatia.

Ministry of Foreign and European Affairs. Foreign

Policy. Multilateral Relations. The European Union strategy for the Danube Region.

Internet 23: http://www.slap.hr/ (20.01.2017). Slap.
Internet 24: http://dcsf.danubestrategy.eu/danubecivil-society-forum-eu-strategy-danube-region/ guiding-principles-civil-society-danube-basin (20.01.2017). Statutes of the Danube Civil Society Forum.

Internet 25: http://www.vusz.hr/info/radna-zajednica-podunavskih-regija (20.01.2017). Vukovar-Srijem County. Working Community of the Danube Region. 